\title{
SUSTAINABLE, SMART AND RESPONSIBLE NATURE PARK TOURISM
}

\author{
Elina Konstantinova ${ }^{1}$, Aija Persevica ${ }^{2}$, Agnese Jenina ${ }^{3}$ \\ ${ }^{1}$ Dr.oec., associated professor, Ventspils University, Riga, Latvia, \\ e-mail: elina.konstantinova@baltijaskrasti.lv \\ 2 Dr. paed., researcher, Association Baltic Coasts, Riga, Latvia, \\ e-mail: aija.persevica@baltijaskrasti.lv \\ ${ }^{3}$ Mg. sc. ing., researcher, Association Baltic Coasts, Riga, Latvia, \\ e-mail: agnese.jenina@gmail.com
}

\begin{abstract}
The one of the largest nature parks in Latvia is Nature Park "Piejūra". It is a very complicated area due to its valuable and sensitive coastal habitats. On the one hand, it is a territory with rich biodiversity, and on the other hand it is an area actively used by visitors and tourists due to its location close to the capital of Latvia. Therefore, implementation of sustainable nature protection, conservation and management activities is particularly important. However, as the area is widely visited, there is public resistance to the implementation of management activities.

The aim of the research is to identify the level of awareness and attitude of Nature Park visitors in respect of the nature conservation, protection and management activities. To achieve the aim of the research, quantitative research methods have been used.

The data allows us to conclude that the understanding of the necessary nature management and protection activities has become deeper in the society. The public understands the established restrictions and considers that there is no necessity to strengthen the restrictions, but only to promote their observance. The study confirms that the attitude towards and understanding of the nature conservation activities changes in the society if there is enough information provided and the necessity for the activities is explained.
\end{abstract}

Keywords: attitude, awareness, conservation, management activities, nature, protection. JEL code: Z390.

Received: 18 March 2021 Revised: 26 March 2021 Accepted: 6 April 2021

Published: 10 December 2021

\section{Introduction}

One of the largest nature parks in Latvia is Nature Park "Piejūra" (hereinafter - the Nature Park), which represents the habitats and species of the Boreal region and is one of the most important natural territories in Europe. Conservation of these sensitive coastal habitats is becoming more and more topical in the entire territory of Europe due to the increase of the anthropogenic load on the coastal territories, as well as the increasing severity of storms and subsequent level of coastal erosion.

At the same time the Nature Park is very heavily used area by visitors and tourists due to its location close to the capital of Latvia and beautiful

This is an open access article under the Creative Commons Attribution 4.0 International License 
nature, including sandy beaches. According to the Central Statistical Bureau of Latvia, approximately $32 \%$ of the population live within the territory of the Nature Park or in close proximity to the Nature Park. Besides that, urbanised territories within the park and surrounding the park have the highest human density in the country - 2511.1 inhabitants/sq.km (Central Statistical Bureau, 2011).

Based on the abovementioned, a conflict arises - on the one hand, the Nature Park is an area of a high biological value and one of the most protected areas in Latvia, and on the other hand it is a territory with high anthropogenic pressure, as it is located nearby the most populated area in Latvia.

As the Nature Park is a very vulnerable territory and a highly visited tourism object, it is necessary to find a balance between visitor needs and sustainable nature management activities.

European Union co-funded LIFE+ programme project "Coastal Habitat Conservation in Nature Park "Piejūra" (LIFE15 NAT/LV/000900) (hereinafter - LIFE CoHaBit) has been implemented to plan and carry out scientifically based sustainable territory management activities. The main aim of the LIFE CoHaBit is mitigation of the heavy anthropogenic pressure and restoration of the vulnerable coastal habitats in the Nature Park.

Numerous studies have shown that conflicts may exist between the management of protected areas and the interests of visitors and residents of nearby areas (Guzman, et al., 2020). Therefore, public information campaigns were started already at the beginning of the project. Nevertheless, during the implementation of the Nature Park management activities, the LIFE CoHaBit project encountered significant public resistance to the scientifically based and expertly determined work carried out.

Negative societal perception of protected area management can seriously endanger these vulnerable areas. (Anthony, 2007).

The aim of the research is to identify the awareness and attitude of Nature Park visitors in respect of the nature conservation, protection and management activities. To achieve the aim of the research, quantitative research methods have been used.

\section{Research results and discussion}

In recent years, particularly in developed countries, environmental impacts have been purposefully reduced (Venter et al., 2016) and protected areas have been expanded to cope with the degradation of natural ecosystems (Ficko et al., 2019).

At a time when biodiversity is declining rapidly (Tittensor et al., 2014) a large part of the society has understood the necessity for nature protection 
activities. Slowly the society is beginning to realise that nature protection does not contradict human progress, and the value of nature does not go above human needs (Pearson, 2016). The sustainability of the environment is closely related to thoughtful use of the nature and its numerous resources, which ensures the source for human existence (Okaba, 2005).

According to the Latvian Sustainable Development Strategy 2030, the Nature Park is defined as a space of national interest importance for its outstanding value for sustainable development of Latvia, preservation of identity, and strategic resources for development of the Latvian state (Sustainable Development Strategy 2030). The Baltic seacoast is one of the most valuable areas where conservation of nature and culture heritage must be in balance with economic development.

The Nature Park is one of the most visited NATURA 2000 territories in Latvia for recreational purposes. The municipalities that lie within the territory of the Nature Park are residing areas for $32 \%$ of the total number of inhabitants of the country, and the territory has a higher population density than any other region of Latvia.

A study conducted in 2015 showed that a significant part of the Nature Park visitors was from Riga (Jenina, 2015). The most important value that people look for in the natural areas that are located nearby cities, is the opportunity to relax in a peaceful and natural environment (Reke 2018).

It is assumed that each visitor of the Nature Park crosses the vulnerable habitats at least twice during a single visit, and particularly in these places the stress caused by the anthropogenic load can be identified. Visitors usually do not intentionally destroy habitats, but increase the negative impacts caused by anthropogenic pressure due to lack of appropriate infrastructure and a low level of awareness among the visitors.

Within the framework of the LIFE CoHaBit project, significant public education activities were carried out to explain the implemented management and conservation activities, thus not only increasing the understanding of the performed activities but also changing the public's attitude to nature conservation. Studies show that two-thirds of the case studies recorded some behavioural change in the desired direction after the intervention (Hardeman et al., 2002). Both the theory of reasoned action and the theory of planned behaviour state that people make quite rational decisions on the basis of a systematic evaluation of information available to them (Ajzen et al., 1980).

\section{Methodology}

In order to achieve the aim set and to identify the visitor attitude towards the protection of the Nature Park and implemented management activities, a questionnaire was developed. 
Both quantitative and qualitative data were obtained and analysed within the research. The questionnaire survey was conducted at two stages - at the beginning (pre-test) of the implementation of the Nature Park management activities and after (post-test) their completion. Within the framework of this study, public information campaigns can be considered as interventions.

Data for the pre-test were obtained in the period from 08/10/2018 to $24 / 10 / 2018$ by gathering the opinions of 506 respondents. Data for the posttest were obtained in the period from $25 / 02 / 2021$ to $08 / 03 / 2021$ by gathering the opinions of 272 respondents. Data obtained electronically were acquired from the pre-test platform visdati.lv and the pre-test platform surveymonkey.com.

The collected data were analysed using the SPSS data processing tool, performing descriptive and inferential statistics. Pre- and post-test respondents were randomly selected participants who visited the Nature Park and had shown interest in completing the questionnaire.

The profile of the average respondent is as follows - a female with a master's degree, aged 40 to 62, who lives in Riga.

\section{Research results}

Comparing the pre- and post-test results, it has been concluded that there are statistically significant differences in the respondents' understanding of the necessary Nature Park management and conservation activities.

The results show that there are statistically significant differences $(p=0.001)$ between the pre- and post-test respondents' assessment about restrictions established in the Nature Park.

Figure No.1 shows the respondents' attitude towards the restrictions established in the Nature Park.

As it can be seen, a higher proportion of pre-test respondents supported strengthening the restrictions (36\%). At the same time, approximately the same proportion of respondents (31\%) thought that the restrictions were appropriate and there was no need to strengthen them.

It is important to note that a significantly higher proportion $(45 \%)$ of post-test respondents believed that the restrictions should be maintained as they are at present, while the pre-test participants felt that the restrictions should be strengthened.

A proportionally equal group $(6 \%)$ of both pre- and post-test respondents believed that the restrictions should be reduced. 
The results obtained show that society is responsible and believe that in order to preserve the values of nature, there must also be appropriate restrictions.

Statistically significant differences were also observed $(p=0.022)$ between the pre- and post-test respondents' opinions on the question about necessity to implement the requirements that correspond to the Blue Flag beaches in the Nature Park.

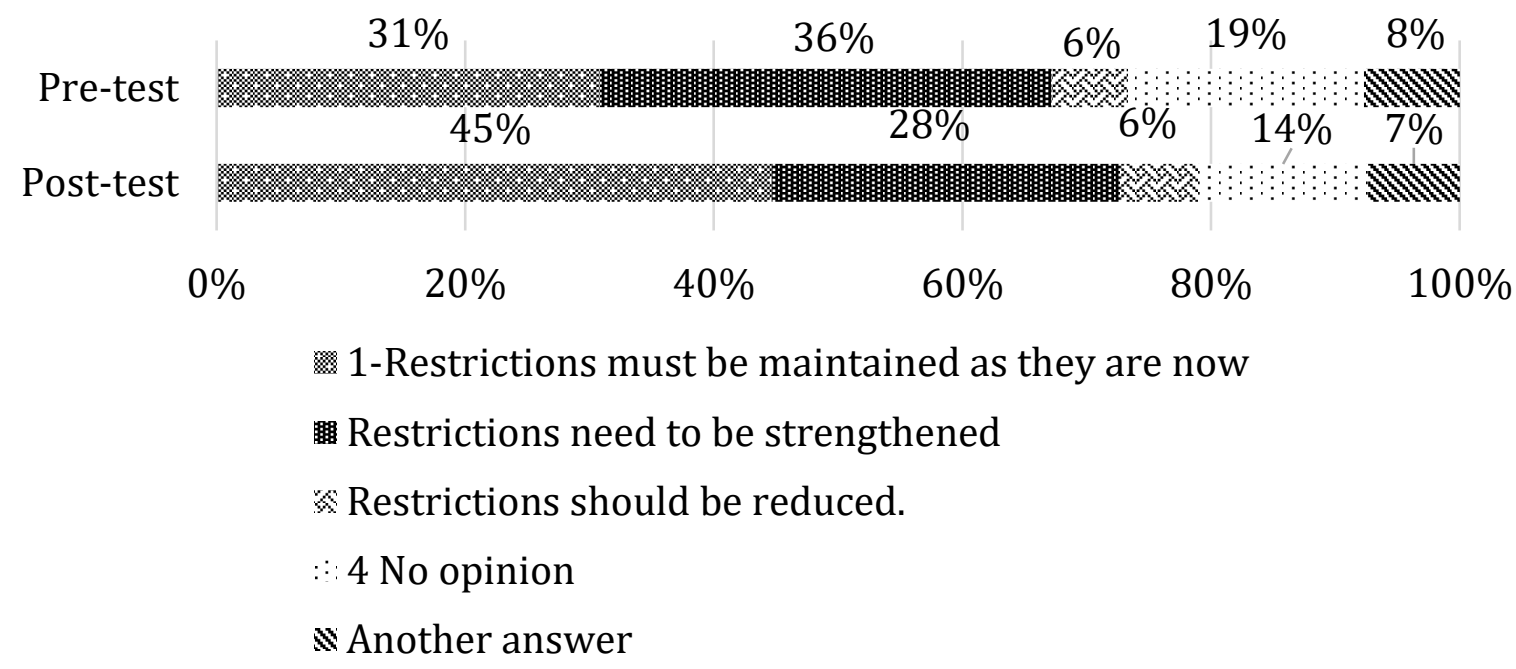

Fig.1 Percentage breakdown of respondent assessments of the restrictions currently established in the Nature Park "Piejūra" (compiled by the author)

Analysing the respondents' opinions regarding the necessity to implement the requirements that correspond to the Blue Flag beaches in the Nature Park (Fig.2), it was concluded that the majority of pre-test respondents agreed with the necessary beach improvements (53\%). Only $16 \%$ of pre-test respondents did not agree with the idea to transform beaches according to Blue Flag requirements.

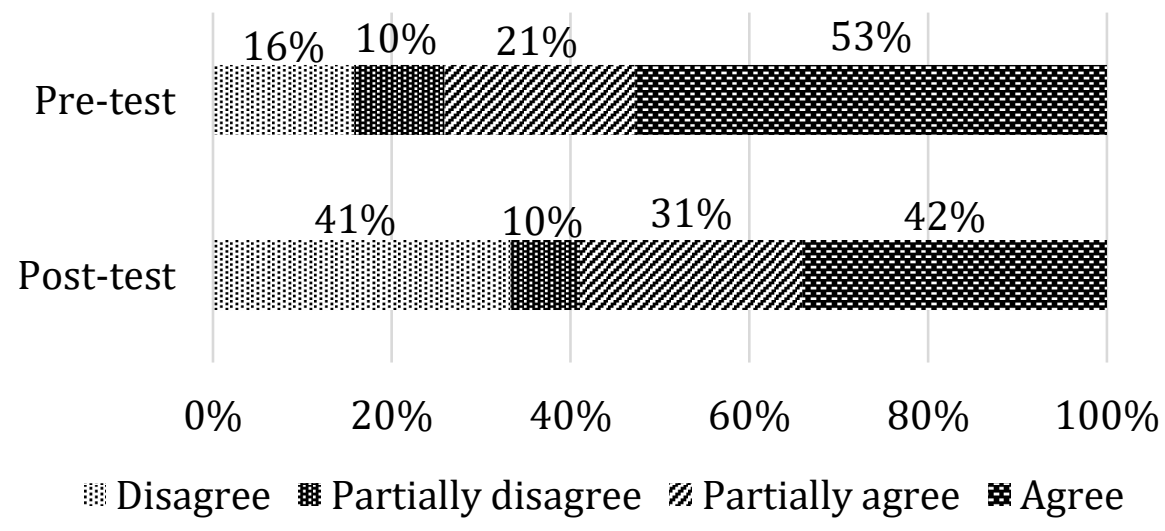

Fig. 2 Percentage breakdown of respondent assessments of the necessity to ensure requirements to create Blue Flag beaches in the Nature Park territory (compiled by the author) 
While the opinions of the post-test respondents are divided - an equal number of the respondents' support (42\%) the necessity to ensure appropriate requirements for Blue Flag beaches, and an equal number (41\%) of the respondents do not agree with such a need.

The obtained results confirm the conclusion drawn within other studies that people look for natural areas, not for purposefully developed and improved beaches.

Although the obtained results may look like that the respondents' opinion on the nature park management activities has become more tolerant, the position of the post-test respondents on the severity of penalties is stricter (Fig.3). The results show that there are statistically significant differences between pre- and post-test responses $(p=0,014)$ in respect of the question about penalties for violations of the rules.

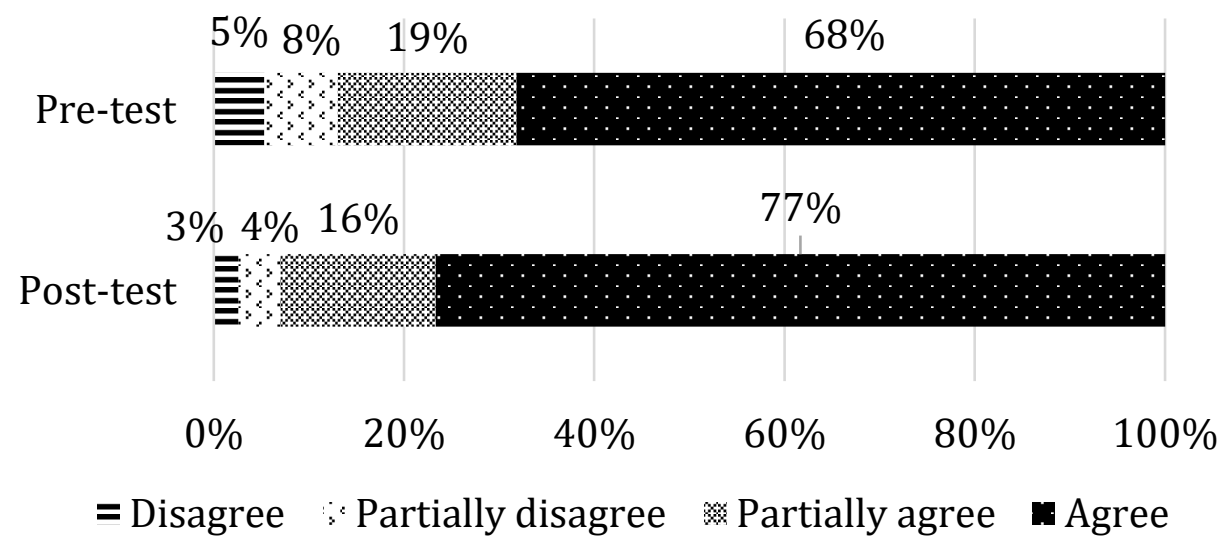

Fig.3 Percentage breakdown of respondent assessments of the necessity for more severe penalties for dune devastation (compiled by the author)

A significant majority of post-test respondents (77\%) believe that park visitors should be punished more severely for dune devastation.

The results show that a larger proportion of pre-test respondents believe that violations should not be penalised. $8 \%$ partially disagree that offenders should be punished more severely and 5\% completely disagree that offenders should be punished more severely. In contrast, the position of post-test participants is less lenient - only 4\% partially disagree and 3\% completely disagree that offenders should be punished more severely.

Based on the obtained results, it can be hypothetically concluded that Nature Park visitors' knowledge has become more comprehensive. Visitors understand the need to comply with the restrictions, as well as understand the justification of these restrictions and do not see the necessity to strengthen the restrictions. At the same time, the public is strict about 
complying with these restrictions, namely, if the rules are not followed, the action must be clear and firm.

The second part of the research was focused on assessing visitors' attitude to and awareness about the management activities that have been implemented in the Nature Park within the LIFE CoHaBit project.

Based on the obtained data in post-test research, it has been concluded that there is a relatively lower level of visitor awareness about the necessity to control invasive species, as well as the necessity to improve the quality of coastal wooded dunes. It is important to mention that there was a great resistance to the activities that was carried out to naturalise seaside wooded dunes. A higher visitor awareness was about the necessity to implement erosion risk reduction activities as well as the restoration of coastal grasslands.

A Pearson correlation analysis performed showed correlations between the visitors' awareness of the necessity for Nature Park management activities and the implemented conservation and protection activities in the particular territory (Table 1).

\section{Table 1 Correlations between the visitors' awareness of the necessity for Nature Park management activities and the implemented ones}

(compiled by the author)

\begin{tabular}{|c|c|c|c|c|c|}
\hline & \begin{tabular}{|l} 
Visitor \\
awareness \\
about \\
restriction of \\
alien species \\
\end{tabular} & \begin{tabular}{|l} 
Visitor \\
awareness about \\
restoration of \\
coastal \\
grasslands \\
\end{tabular} & \begin{tabular}{|l|} 
Visitor \\
awareness \\
about \\
reduction of \\
erosion risk \\
\end{tabular} & $\begin{array}{l}\text { Visitor } \\
\text { awareness about } \\
\text { improvement of } \\
\text { the quality of } \\
\text { wooded dunes }\end{array}$ \\
\hline \multirow{9}{*}{ 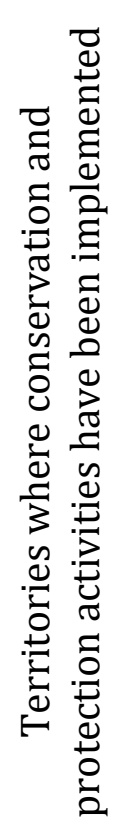 } & Bullu sala & .088 & & & \\
\hline & $\begin{array}{l}\text { Kalngale } \\
\text { dunes }\end{array}$ & .034 & & & \\
\hline & $\begin{array}{l}\text { The estuary of } \\
\text { the Gauja } \\
\text { River }\end{array}$ & .078 & & & \\
\hline & $\begin{array}{l}\text { Vakarbullu } \\
\text { grasslands }\end{array}$ & .074 & $.244^{* *}$ & & \\
\hline & $\begin{array}{l}\text { Daugavrīva } \\
\text { grasslands }\end{array}$ & .021 & $.260^{* *}$ & & \\
\hline & $\begin{array}{l}\text { Carnikava } \\
\text { dunes }\end{array}$ & & & $.216^{* *}$ & $.179^{* *}$ \\
\hline & $\begin{array}{l}\text { Garciems } \\
\text { dunes }\end{array}$ & & & $.252^{* *}$ & \\
\hline & Lilasete dunes & & & $.270 * *$ & $.222^{* *}$ \\
\hline & $\begin{array}{l}\text { Mangalsala } \\
\text { dunes }\end{array}$ & & & $.234^{* *}$ & .097 \\
\hline
\end{tabular}


As can be seen in Table 1, there are no correlations between the visitors' awareness of and attitudes towards the restriction of alien species in the Nature Park. The reason for the lack of correlations can be explained by the fact that a large number of respondents did not have an opinion on the work performed, which can be largely explained by the fact that the work is less visible compared with other management activities.

Statistically significant, but relatively weaker correlations are between the visitor awareness of the necessary erosion risk reduction activities, coastal grassland restoration activities and forest dune quality improvement activities, and the attitude towards the activities performed in the project areas.

The variables between which the correlations are very weak are the visitors' awareness of the necessity to improve the quality of wooded dunes and the attitude towards the activities performed in the Carnikava and Mangalsala areas.

It is important to mention that these are the areas where the LIFE CoHaBit project faced the greatest public resistance during activity implementation.

\section{Conclusions and suggestions}

The obtained results show that Nature Park visitors are educated and positively oriented towards the currently implemented nature protection restrictions and necessary activities to preserve nature values.

The creation of Blue Flag beaches involves significant improvement and, in a sense, redevelopment of the beaches. Such activities, on the one hand, clean and maintain the territory, but on the other hand transform it and most likely also increase the anthropogenic pressure. The study concludes that society currently does not want all beaches to be well-maintained, but to have access to a natural environment where it is possible to relax and enjoy the nature.

The data allows us to conclude that the understanding of the necessary nature management and protection activities has become deeper in the society. The public understands the established restrictions and considers that there is no necessity to strengthen the restrictions, but only to promote their observance. It is not the strength of the restrictions, but understanding of and compliance with them that will contribute to nature protection. According to the ecosystem services approach, the value of nature is its sustainable use to promote human development. If the territory is not available to society, it will no longer be 'so valuable', because a human will not be able to acquire this value. The only condition is how this value is used - thoughtfully and sustainably or selfishly and irreversibly? 
The study confirms that the attitude towards and understanding of the nature conservation activities changes in the society if there is enough information provided and the necessity for the activities is explained.

Before implementing future Nature Park management activities, it is necessary to plan and carry out in-depth public education activities, thus each visitor will not only better understand the validity of and necessity for the activities, but changes in their behaviour and attitude towards the nature area and its values are also expected.

\section{Acknowledgements}

The research underlying this manuscript has been conducted within LIFE+ programme "LIFE Nature and Biodiversity" project LIFE15 NAT/LV/000900 "Coastal Habitat Conservation in Nature Park "Piejūra""co-funded by the European Union.

\section{References}

1. Ajzen, I., Fishbein, M. (1980). Understanding Attitudes and Predicting Social Behaviour. Prentice-Hall.

2. Anthony, B. (2007). The dual nature of parks: attitudes of neighboring communities towards Kruger National Park, South Africa. Environmental Conservation 34(3), 236-245.

3. Ficko, A., Bončina, A. (2019). Public attitudes toward environmental protection in the most developed countries: The Environmental Concern Kuznets Curve theory, Journal of Environmental Management, 231, 968-981.

4. Guzman, A., Heinen, J. T., Sah, J. P. (2020). Evaluating the Conservation Attitudes, Awareness and Knowledge of Residents towards Vieques National Wildlife Refuge, Puerto Rico. Conservation and Society, 18(1), 13-24

5. Hardeman, W., Johnston, M., Johnston, M. et al. (2002). Application of the theory of planned behaviour in behaviour change interventions: A systematic review. Psychology and Health, 17, 123-158. https://doi.org/10.1080/08870440290013644a

6. Jeñina, A. (2015). Dabas aizsardzības un vietas attīstības interešu saskan,ošana dabas parkā „Piejūra” Carnikavas novada teritorijā. Maǵistra darbs.

7. Okaba, B. O. (2005). Petroleum Industry and the Paradox of Rural Poverty in the Niger Delta. Benin City: Ethiope Publishing

8. Pearson, G.R. (2016). Reasons to Conserve Nature. Trends in Ecology \& Evolution 31(5).

9. Rek̦e, A. (2018). Rīgas Piejūras dabas teritoriju plānošanas problemātika un risinājumi. Maǵistra darbs

10. Saeima of the Republic of Latvia (2010). Sustainable Development Strategy 2030 Retrieved from https://www.pkc.gov.lv/sites/default/files/inlinefiles/LIAS 2030 parluks en 0.pdf

11. Tittensor et al. (2014). A mid-term analysis of progress toward international biodiversity targets. Science 346(6206), 241-244

12. Venter, O., Sanderson, E.W., Magrach, A., Allan, J.R., Beher, J., Jones, K.R., Possingham, H.P., Laurance, W.F., Wood, P., Fekete, B.M., Levy, M.A., Watson, J.E.M. (2016). Sixteen years of change in the global terrestrial human footprint and implications for biodiversity conservation, Nat. Commun., 7, 12558. 